\title{
Issues On Waqf Land Registration Process In Malaysia And Improvement Proposals
}

\author{
Noor Azimah Ghazalia, Ibrahim@atan Sipana*, Fauziah Rajib, Mohammad Tahir Sabit Haji Mohammadc \\ a Faculty of Built Environment and Surveying, Universiti Teknologi Malaysia, 81310, Johor, Malaysia \\ University of Reading, Johor, Malaysia \\ cFaculty of Law, International Islamic University Malaysia, IIUM \\ *Corresponding author: ibrahimsipan@utm.my
}

\section{Article history}

Received: 2019-04-07 Received in revised form: 2019-08-10 Accepted: 2019-08-16 Published online: 2019-10-31

\begin{abstract}
Religious aspect of charity is connected closely with Islamic endowment (waqf plural awqaf) and becomes a key Islamic institution within the Muslim world for more than a millennium. Globally including Malaysia, waqf widely relates to land and buildings. Under Islamic Law the land or any property declared by individuals to become waqf is considered binding and valid as soon as the donor implies or expresses the intention clearly. There are 5 valid elements (rukn) of waqf declaration under Islamic Law. However, under Malaysian Land Law, waqf properties need to be registered at Land Office after a waqf declaration at State Islamic Religious Council (SIRC). The rational is to ensure land indefeasible ownership under National Land Code (NLC) 1965. However, there are few issues in the procedure existed. Therefore, this paper highlights nine issues from organisation and the donors involved in registration process of waqf land and suggesting nine improvement proposals by State Islamic Religious Council Johor. The approach adopted is 'Content Analyses and 'System Approach'.
\end{abstract}

Keywords: Waqf, land, registration, process. 


\subsection{INTRODUCTION}

Among many assets, land is the highly valuable. Land holds a unique and essential place in social, political, environmental and economic theories. It includes all natural resources, materials, airways, as well as the ground supporting all life and stands at the center of human culture and institutions. All people, at all times, need land for any activity. Therefore, land is a valuable asset of every state. With the high demands, needs and scarcity of land, it is crucial for land to be registered and managed properly. Therefore, all the lands must be registered for the Land Title as a mean to provide the indefeasible and recognized information of ownership of the land which is compelled under the Malaysian federal law in Section 340 NLC. At the same time, under the Islamic Law the land or any property declared by individuals as waqf is considered binding and valid as soon as the donor implies or expresses the intention clearly. Thus, the effect of waqf is set to be perpetuity, irrevocable and inalienable.

\subsection{The Research Question}

Declaration at State Islamic Religious Council (SIRC) is not considered binding and valid until it is registered at Land Office. However, the process to register the waqf land at land office is time consuming and risky as the taxing procedure may result in the waqf land to be lost and be challenged in court. Therefore, these problems lead to several research questions:

i What is the Islamic concept of valid and enforceable declaration of waqf?

ii. What is the current process of waqf land registration in Malaysia?

iii. How to improve efficiency of waqf land registration process in Malaysia?

\subsection{The Aim and Objective}

From the problem statement above, the waqf land declaration and registration system in Malaysia need to be reviewed. Therefore, the aim of this research is to develop and improve sharia compliant structure for effective declaration and registration system of waqf land applicable in all states in Malaysia.

i. To examine the concept of valid waqf declaration according to Islamic Law and Malaysian Legal System

ii. To analyse current process of waqf land registration system in Malaysian

iii. To propose improvement solutions for registration process of waqf land in Malaysia

\subsection{METHODOLOGY}

This research is divided into three main stages; firstly is the theoretical stage, secondly the empirical stage and thirdly the evaluation stage. The research begins with the identification of research problems, aims and objectives of the study. In the theoretical stage, it selects and elaborates the legal literatures and provides the review required. Second, the empirical stage will involve the process of collecting qualitative data through interviews and finally, the third stage is the data analysis and evaluation.

\subsection{Methodology in Literature Review}

The research begins with the identification of research issues, aims and objectives based on problem statement. In theoretical stage, it moves on to elaborate on the literature review. Second, 
the empirical stage which involve the process of collecting the qualitative data, interviewing and few questionnaire. Third the data is analysed and evaluated.

The communication of law in this research is divided into two sources of law. First, is the Sources Islamic Law and second is Sources of Malaysia Legal System. The cognitive nature of Islamic theory system are Quran and Sunnah (M.H. Kamali, 1998). Juristic Interpretation, fatwa, judicial decisions also contributed to the formation of Islamic Law.

i. Juristic Interpretation is the four imamis leading in four school of law; Hanafi, Hanbali, Syafie and Maliki

ii. Fatwa is a non-binding judgment on a point of Islamic law given by a recognized religious authority

iii. Judicial decisions are based on obiter dictum (purposive principal) and ratio decindi (binding principal) and the fatwa or jurists opinion which are followed by the judge

Whereas, communication of Malaysia Legal System Sources is divided into Statutes, Judicial Decision and Academic Opinion hierarchy interrelated. The wholeness of the system is involving the local and foreign country's source of law. This method of inductive method will be applied by zooming into the law as it is, as applicable to certain issue. Then, to find out how the law ought to be, the method of deductive method is applied.

i. Inductive method is based on broader generalizations and theories of law, begins to then detect patterns and regularities, formulate some tentative hypotheses (major and minor premises) to explore, and finally ends up developing some general conclusions or theories (A. Crossman, 2011)

ii. Deductive method is based on specific hypotheses (major and minor premises) of law that can be tested by specific data (i.e interpretation rules) leading to a confirmation (or not) of the original theory and arriving at a conclusion (A. Crossman, 2011)

\subsection{Methodology in Empirical Study.}

Method of collecting Primary data uses the methods of: Interview- unstructured: narrative and oral historical technique, structure: scheduled interview; The respondent will be chosen by cohort and panel study which the respondent is taken based on common characteristic related to this research such as the respondent are the administrator of waqf, working in waqf institutions and applying waqf registration process. Quota sampling and judgmental sampling or purposive sample is appropriate to researcher to choose the respondents. Quota sampling is a method where the respondent is chosen by certain characteristics based on researcher's judgment. The sample is selected by from a location convenient to the researcher and the characteristic of respondent relevant to the research. Respondents are among:

i. Assistant Director, Waqf Department, Johor State Islamic Religious Council

ii. Assistant Director, Registration Department of Department of Lands and Mines of Johor

iii. Amin Baitulmal Assistant, Wakaf dan Zakat, Johor State Islamic Religious Council of Kota Tinggi.

iv. Land Administrator Assistant, Registration Department of Land Office of Kota Tinggi District

v. Executing Staff of SIRCJ and Kota Tinggi Land Office 
Method of reasoning used for data analysis are; open texture, role of analogy, combines analogy, elements of induction and deduction (Farrar, 1997; Knight And Ruddox, 2008).

\subsection{LITERATURE REVIEW ON VALID WAQF DECLARATION}

Imam Ahmad Bin Hanbal opined waqf is related to the word of habastu, wakaftu, sabaltu, and tasadaqtu all may have derived from the words spoken by the Prophet (pbuh) "babasta" or habbis al al asl wa sabbil thamarah. Habs carries the same meaning as to hold, confine, prohibit, detain, prevet, or restrain (Rukmana, 2010: Hamid and Mohammad, 2012).

Literally, waqf is derived from the hadith reported by Ibn Umar, which contains the word habs that is the same as waqf (Hashim, 2007; Kahf, 2003; Hamid and Mohammad, 2012). Generally, it is understood from the hadith, that Umar (r) has declared that the given property be not transferred under gift or sale or part of inheritance but benefits of it be distributed in a way of Allah (swt). Hence, it is shown that waqf property is inalienable, irrevocable and exists in perpetuity (Osman, 2008; Mohammad, 2011).

The perpetuity of waqf is integral element of sustainability of waqf. Waqf's role is important in improving the welfare of ummah (Kahf, 2012). Therefore, waqf shall be conserved and protected permanently to keep it contributing the ummah in all time. In order to conserve and protect the waqf property, it shall be administered properly. Waqf property involves registration, law and regulation compliance and asset management including investment and development finance, maintenance and repair, protection and generation of income all the time (Mohammad, 2011). For all, registration of waqf property is essential today, because lack of attention to it would be management procrastination and may leads to loss of waqf property (Omar, 2013; Chowdhury et. al, 2011). The loss of waqf property may be avoided if the law and procedure for its registration could be based on Islamic law therefore conforming to the spirit of the Malaysian Federal Constitution (Omar, 2013). Religious aspect of charity is connected tightly with Islamic endowment (waqf plural awqaf) and becomes key Islamic Institution within the Muslim world for more than a millennium (Augustinus, 2005).

There are generally two basic forms of waqf which is public and family or private waqf. In the family endowment (waqf abli) property, its income is held for the family of its founder, until the end of his or her descendants, whereupon it is diverted to a charitable purpose. The charitable or public endowment (waqf khairi) involves the permanent dedication of property to charitable purposes (Chepkwony, 2008; Esmaeil, 2010). Waqf khairi can be divided into general waqf and special waqf (Augustinus, 2005). At the same time, under Islamic Law the land or any property declared by individuals to become waqf is considered binding and valid as soon as the donor implies or expresses the intention clearly (Hamid and Mohammad, 2012). Thus, the effect of waqf is set to be perpetuity, irrevocable and inalienable (Osman, 2008; Mohammad, 2011). However, within the context of Malaysia legal system, waqf properties need to be declared at State Islamic Religious Council (SIRC) or Majlis Agama Islam Negeri and registered in the land office (Mohamood, 2006). These two systems of waqf declaration and registration is quite challenging todays when they require procedures/steps under two different laws/regulations that may result in unintended effects from perspective of the donors.

\subsection{Valid Waqf under Islamic Law}

According to Muslim Jurists, waqf could be enforceable in law when waqif express his/her intention to donate his property as waqf. The intention of the waqif can be enforced if he has fulfilled all elements with specific conditions of a valid waqf declaration. To Hanafis valid 
declaration is made when ijab and qabul are made. To other jurists, a valid deed is concluded if there is valid declaration (sighah), by a qualified donor (waqif), for recognized beneficiary (mawquf alaib), of a permissible subject matter (mawquf). A manager (nazir) has to be appointed too, such in Figure 1 (Hamid and Mohammad, 2012).

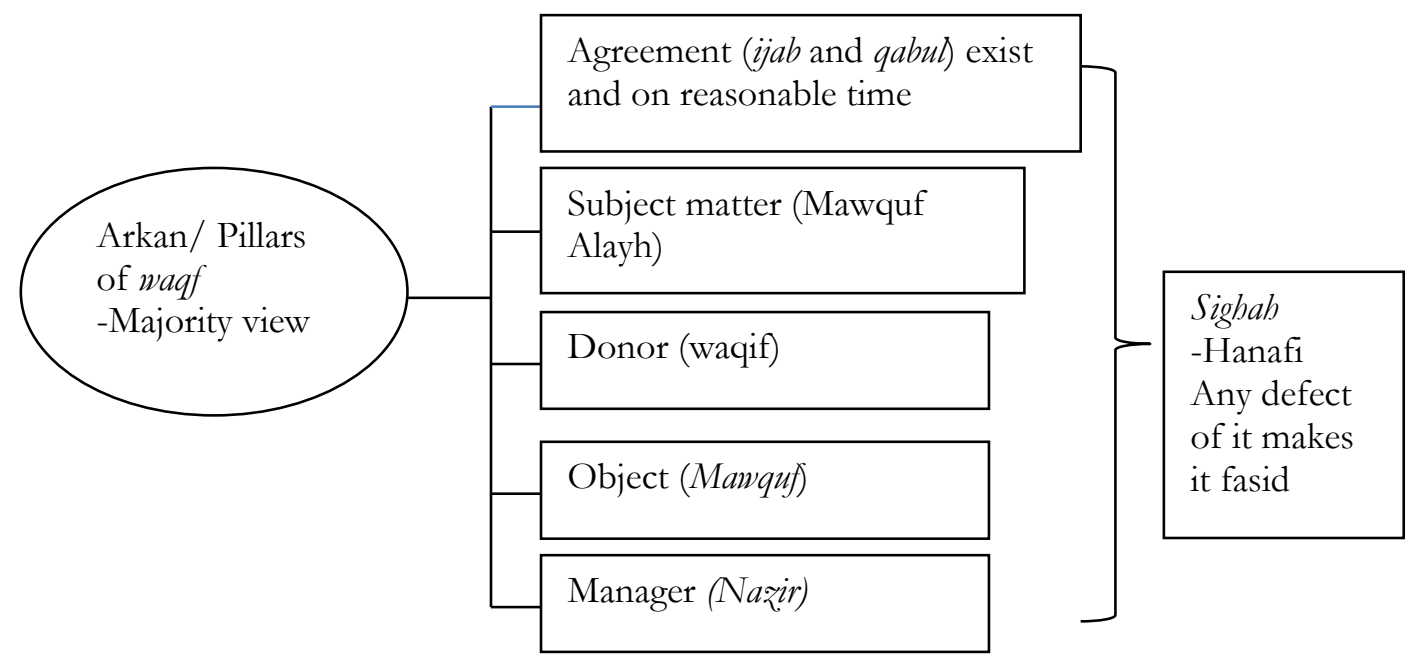

Figure 1: Elements of Valid (Sabib) Waqf

a. Sighah means ijab (offer) and qabul (acceptance). Just like any other contract, waqf contract is created when waqif declare his intention to create waqf (orally or in writing). According to Syafie's law, the acceptance of beneficiaries is needed and if beneficiaries refuse at first place, he/she may accept it later (nafiv) otherwise it will be void (batil). However, Malikis opined even if the specified beneficiaries refuse, the declaration of waqf is binding (nafis), but the subject matter of waqf given to the next beneficiaries or to the poor (Hamid and Mohammad, 2012, 16). According to Maliki, Ahmad ibn Hanbal and Syafie, delivery of possession is not a necessary (nafir/ghair lazim/jaiz) (Osman, 1982, 128; Khassaf, 1904, 113).

b. Donor or waqif is someone who donates his property as waqf. The existence of waqif is one of the main elements that constitute a valid waqf (sabih/nafir) (Hamid \& Mohammad, 2012, 14; Husain, 2014). For a contract or the deed of waqf to be binding or enforceable immediately (nafiz/lazim), it requires the waqif to be qualified, that is he/she must be of full age (aqil baligh), sane and capable of declaring his/her will or has obtained faculty of disposition over his property, otherwise it will be invalided (ghair sabib/batil) (Ali, 2009, 10).

c. Object (mawquf alayh); according to Syafie's School and Imam Mohammad alShaibani, waqf without purpose is void (bati) (Osman, 1982; Ramli, 1938, 370; Qudamah, 1947, 567-68). Purpose of waqf may or not with pious intention and in favor of poor and rich and it is intended to be charitable. The subject of waqf varies such as wedding gift to girls whose families were unable to provide them, freeing prisoners, endowment for travellers of goods, clothing and expenses, paving streets, building mosque or religious houses, colleges and mausoleums.

d. The subject matter (mawquf) of waqf is defined as something valuable, useful, helpful and not to be harmful to the beneficiaries (sahih) (Osman, 1982, 29). It is possible to be money or property either movable or immovable (Osman, 1982, 55; Shafie, 1961, 59; 
Khassaf, 1904, 34-35). Besides that, the motive of waqif in doing waqf is to the approach to Allah (qurbah) (Osman, 1982, 30; Quran, 2: 273; 10: 60).

e. Manager (nazir); the administration of waqf is in the hand of manager (nazir) who could be one or more people. All Sunni schools 'Ijma' (agree consensually) that Mutawalli must be of a genuine character and competent to fulfill the duties of the office (Osman, 1982, 169). Literal Rule is rords be given by their ordinary, literal, grammatical meaning, day to day meaning words it use the language of the ordinary citizen (Pacific, 2003). By applying Literal Rule, the words manager is synonym to Nazir, qayyim, Mutawalli or administrator. Mischief Rule is looking to what the law was before the statute was passed in order to discover what gap or mischief the statute was intended to cover. The court is then required to interpret the statute in such a way to ensure that the gap is covered (University, 2014).

A waqf deed can be effective if each of the elements fulfills the required conditions of valid, immediately enforceable contract because Muslim jurists regard waqf as a contract that is unilateral in nature. For it to be effectively binding, the deed of waqf shall include the conditions based on every elements of the waqf as illustrated in Figure 1.

\subsection{Valid Waqf under Malaysian Legal System}

According to the majority of jurists a valid deed is concluded if there is valid declaration (sighah), a qualified donor (waqif), qualified beneficiary (mawquf alaih), permissible subject matter (mawquf) and manager (nazir) (Hamid and Mohammad, 2012). However, waqf land, in Malaysia, required to be registered before it could be fully utilized or developed including waqf land by several procedures. There are two steps to for the recognition of waqf land. The registration of declaration at SIRC and another registration at Land Office.

Waqf and land matters are within the jurisdiction of State (List II of Fderal Constitution). The State Authority is often considered to be in reference to Sultan (s 5 NLC). While Islamic matters including waqf are within jurisdiction of SIECs, Land Registry or Land Offices handle land matters. Section 4 (1) of the Administration of the Religion of Islam Negeri Johor, 2003, state:

"There shall be a body called State Islamic Religious Council to assist and advise the Sultan in matters relating with Islam"

By refer to NLC where the jurisdiction of the land office is defined in Section 8 of the National Land Code are to: "with the approval of the State Director, enter within and inspect the records of any Land Registry or Land Office in any State." 


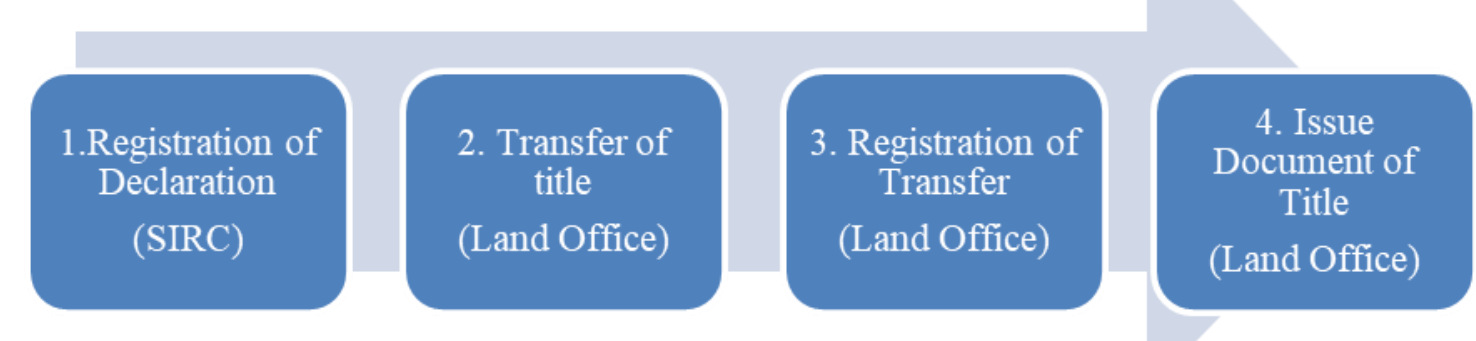

\begin{tabular}{|c|c|c|c|}
\hline $\begin{array}{l}\text { State } \\
\text { Enactments } \\
\text { - Sighab } \\
\text { - Waqif } \\
\text { - Mawquf } \\
\text { - Mawquf Alaibi } \\
\text { - Nazir }\end{array}$ & $\begin{array}{l}\text { NLC } \\
\text { - Transfer Title } \\
\text { - Surrender and Re- } \\
\text { alienated } \\
\text { - Statutory Vesting }\end{array}$ & $\begin{array}{l}\text { Parties involved } \\
\text { - SIRC } \\
\text { - Land Office } \\
\text { - Department of Survey } \\
\text { and Mapping and } \\
\text { Department of Lands } \\
\text { and Mines } \\
\text { - State Authority } \\
\text { - Local Authority }\end{array}$ & $\begin{array}{l}\text { Indefeasible under } \\
\text { - Civil Law } \\
\text { - NLC } \\
\text { - State Enactments } \\
\text { - Court Jurisdiction }\end{array}$ \\
\hline
\end{tabular}

Figure 2: Recently Malaysia Waqf Registration System Framework

As illustrated in Figure 2, in order to make waqf binding, valid and recognized under State Enactments, waqf has to be declared in front of Waqf Officer at SIRC. Generally, the old cases on waqf registration frameworks have a view that regards registration in Land office irrelevant. The validity of declaration of waqf by waqif, without being registered in land office, was considered valid and binding in the following cases:

i. Haji Embong Bin Ibrahim \& Ors V Tengku Nik Maimunah Hajjah Binte Almarhum Sultan Zainal Abidin \& Anor, [1980] 1 MLJ 286. There is no regulation yet of waqf at the time waqif declare the waqf. However, it was held that the Islamic Wakaf Validating Enactment, 1972, has retrospective effect and applies to the wakaf in the present case; the dispositions to strangers were valid under Islamic Law and were saved by sections 2(3) Administration of Islamic Law Enactment, 1955.

ii. G Rethinasamy Lwn Majlis Ugama Islam, Pulau Pinang Dan Satu Yang Lain, [1993] 2 MLJ 166 within the jurisdiction of the civil court plaintiff being a non-Muslim, could not bring an action in the sharia court. Second defendants had been occupying part A for more than 12 years before 1966; they had not taken any action to determine their interest. Section 105 of the Enactment applies whether the land is 'wakaf' land or otherwise, provided: there was a mosque or something related to it or used for its purposes on the land, and the land is not state land. The defendants need not prove that the land was 'wakaf' land in order to get the benefit under s 105. Part A, therefore, was vested in the first defendant. The plaintiff's title to part A was defeasible.(4) The defendants were able to prove that part A was wakaf land by user and the land was not subject to the National Land Code 1965.

Currently waqf is registered by three methods such as in Table 1 to establish the status of such lands as waqf lands with the assistance of the Department of Survey and Mapping and Department of Lands and Mines (M. Afendi \& Sayuti, 2012). 
Table 1: Method of $W$ aqf Land Registration in Land Office at Malaysia

\begin{tabular}{|l|l|l|l|}
\hline No. & Method & Provision of NLC & Forms \\
\hline 1 & Transfer of Title & Section 215 & form 14A and form 14B \\
\hline 2 & $\begin{array}{l}\text { State Surrender and Re- } \\
\text { alienation }\end{array}$ & section 195 & form 12A and form 12B \\
\hline 3 & Statutory Vesting & Section 416 & form 30A and form 30B \\
\hline
\end{tabular}

Later, the form shall be submitted to Land Administrator, Department of Survey and Mapping and Department of Lands and Mines, and State Authority including Local Authority. Indefeasibility does not mean invalidity of an unregistered dealing. Within Islamic law, waqf is considered binding and valid after existences of five elements of waqf are compiled (Figure 1). General Law of contract also would be relied by courts to recognize the validity of dealing.

The length and complicated procedures to create waqf by individual, organizations/ company/ developer and State Religious Council (SIRC) required for registration of transfer of title from waqif name to waqf may result in termination of waqf against the rule in Islamic law and above precedents of local courts when heirs and other parties try to revoke and challenge the status of waqf.

Silence of law about the power of State agencies or Local Authority to declare waqf (irsod), such as for burial ground, school and mosque makes the matter more complicated. Currently, only Manual of Zakat, Hajj and Waqf Department/ Jabatan Wakaf Zakat dan Haji (JAWHAR Manual) has mentioned on waqf irsod but no details provision implied. States Enactment is only provided "mosque and grave built on land is considered as waqf property. However, there is only within Negeri Sembilan Waqf Enactment and Selangor Waaf Enactment. Even though, under civil law no waqf exists if it's only made by state (waqf irsod). No waqf was declared without power (by State Authority) to say so and SIRC was not considered as trustee (direct interest holder) by civil court. State Authority set up a policy that all the reserve land which is for religious purpose and social activities are within the authority of JAIS and MAIS as the sole trustee of the land (K. Jamil, 2012). However, not mentioned the land is considered as waqf land.

a. Majlis Agama Islam Selangor (MAIS) v Bong Boon Chuen \& Ors [2008] 6 MLJ 488; The learned High Court judge held that MAIS had failed to satisfy the requirements of O $15 \mathrm{r}$ 6(2) of the RHC and that there was no necessity for MAIS to be joined as an intervener. Accordingly, the application was dismissed. The judge held, dismissing the appeal with costs, Court of Appeal agreed with the decision of High Court. Then the Federal Court agreed with the Court of Appeal it was held that for sufficient interest to justify intervention under Order 15 rule 6(2)(b) of the RHC a direct interest must be established. An indirect or commercial interest does not satisfy the requirement. MAIS clearly does not satisfy this requirement. 
Consequently the following may occur:

i) Where the waqf is not recognized based on NLC, Muslims or the beneficiaries may lose their right to be compensated in land acquisition if the land were not declared and registered as waqf as mentioned in Section 416C NLC (M. Afendi \& Sayuti, 2012).

ii) Where the existing methods of NLC which are not designed for waqf are used awqaf are terminated if the legal action to be taken seriously.

iii) Some states which are currently without specific legislation on waqf are left with many weaknesses such as no standardization of practices; lack of detailed laws and procedures as well as no clear rule to declare and register the land under the SIRC and NLC (N.A. Mohamad et. al, 2012).

iv) Interference of jurisdiction in civil court such as Majlis Agama Islam Selangor (MAIS) v Bong Boon Chuen \& Ors [2008] 6 MLJ 488, Civil Court did not consider their jurisdiction on whether or not the declaration by Local Authority (Majlis Bandaraya) could amount to waqf or not and if yes, then it would be within the jurisdiction of Sharia Court

Therefore, it can be summarized waqf has no status until it registered under NLC, registration under NLC requires time, status of waqf land is challenged most of the time at court, SIRC was not fully considered as trustee (direct interest holder) and no clear rule to declare and register the land under the SIRC and NLC. Thus, all of these issues lead to unregistered waqf land and furthered to this research on the respondents view that are scope of work the most related to.

\subsection{DATA ANALYSIS RESULTS AND DISCUSSION}

Initially, the process of waqf declaration in Malaysia is clearly compliant to Islamic Law where the existence of five elements/pillars of waqf shall make the waqf valid and binding. However, under process of waqf registration in Malaysia, they are several problems and leads to unregistered waqf land (with no grant title) as in Table 2.

Table 2: Area of Waqf Land without Grant Title

Source: Auditor General's Report Series 3 (2015)

\begin{tabular}{|l|l|l|l|l|l|l|}
\hline \multirow{2}{*}{ No } & Reason & \multicolumn{2}{l|}{ Total $W$ aqf Property } & \multicolumn{2}{l|}{$\begin{array}{l}\text { Waqf Property which does not have } \\
\text { Grant Title }\end{array}$} \\
\cline { 3 - 7 } & & Total & $\begin{array}{l}\text { Area } \\
\text { Acre })\end{array}$ & Total & Area (Acre) & $\begin{array}{l}\text { Percentage } \\
(\%)\end{array}$ \\
\hline 1 & Mosque & 754 & $1,075.78$ & 386 & 516.86 & 51.2 \\
\hline 2 & Small Mosque & 1,429 & 699.71 & 498 & 273.35 & 34.8 \\
\hline 3 & Religious School & 693 & $1,159.20$ & 198 & 442.21 & 28.6 \\
\hline 4 & Grave & 614 & $2,667.64$ & 364 & $1,510.38$ & 59.3 \\
\hline 5 & Public & 364 & $6,456.00$ & 95 & $2,976.39$ & 26.1 \\
\hline 6 & Mosque and Grave & 14 & 33.47 & 13 & 37.85 & 92.9 \\
\hline Total & & 3,868 & $12,091.80$ & 1,554 & $5,757.04$ & 40.2 \\
\hline
\end{tabular}

According to Table 2, total percentage of waqf property that does not have Grant Title is 40.2 percent which is almost half of total properties. These could lead to the loss of waqf 
properties in the future. Therefore, this research is been carried to figure out the issues and proposed an improvement on every issues existed. There are numbers of issue about waqf registration usually faced by officers and caused varies effects in the future. However, there are certain improvement proposal that is suggested by the officers to overcome the problems and issues. From the Table 2, the officers of SIRCJ and Land Office having quite similar issues and problems within the process of waqf land registration. From the procedure itself to the staff involved, executive authority and heirs. All the issues causes impact and effects to the waqf properties in the future which is caused the properties to be lost, undeveloped and wasted to idle land.

Based on empirical study on data collection, most of the respondents agree current issues on waqf registration are:

\section{i. Bureaucracy}

Management of the Land Office and SIRCJ is mostly binding to standard operation procedure (SOP). However, most of the land office at every district has different SOP. Certain Land Office implements Transfer of Title based on Section 215 (NLC) to register waqf land. Another Land Office at different district implements statutory vesting based on Section 416 (NLC) as method of registration. Therefore, it is confusing for SIRCJ to prepare form and every method consume different time frame to complete the process of registration. Hence, development planning and development cannot be done precisely on the waqf land.

\section{ii. No adjustment among agencies}

Agencies involved in waqf land registration are included Land Office, SIRCJ, Department of Land and Mines, Local Authority and State Authority such as in the Figure 2. Every agencies are different at every districts and State. Because of no waqf regulation in NLC, thus, every agency made different circulation and rules to register waqf land. The process of registration is depends on the understanding of the officer involved to execute the process. Therefore, waqf land ownership solution suggested cannot be implemented by all agencies because no adjustment among them.

\section{iii. Late approval by State Authority}

There are a lot of mechanical procedure to comply before the land is registered such as application and preparing technical progression such as the Layout Plan, Ground Report, Land Reports, Admission Form and Letter, Registration and Vesting, Submitting Notices, Stamp Duties Exemption, Periodic Surveys and Gazzetting Land. All of the process is time consuming. In the meanwhile, idle land will be an opportunity for the invasion.

\section{iv. Objection heirs}

Idle land is also open to third party invasion including the heirs of waqif. The waqif declaration in SIRCJ to donate property as waqf is not yet binding until all the mechanical process is taken. As mentioned earlier, there are numbers of court cases involved the objection of heirs to cancel the land to be registered as waqf land. Therefore, status of waqf land can be challenged in court

\section{v. Ineffective implementation}

Since no standardise provision among states and district, the execution of waqf land Page $\mid 66$

registration is varies in every district and states. Thus, the process of registration is depends 
on the land office and officer involved. Hence, certain officer is well-understand and certain officer just follow the circular made by the land office without fully understand the characteristic of waqf land which is irrevocable, inalienable and perpetuity. Therefore, the process can be delay if the task is not undertaken seriously and ineffectively.

\section{vi. The length of time through the process}

Before the land is registered, there is other mechanical process involved which requires many agencies to approve the application. Hence, it made the process is lengthy to complete the registration and lead to late submission to State Authority

\section{vii. Lack of staff}

There is shortage of staff who knowledgeable in Islamic property to conduct waqf or Islamic property such as wasiah and sadaqah in SIRCJ and also Land Office. Most of the staffs that available are only takes command from officer in the higher rank. Thus, it causes the workload on existing employees and reduces the efficiency of management

\section{viii. No Land Expertise}

As in Land Office, SIRCJ is also lack of staff or officer who truly understands the land matter. Thus, to conduct land registration in land office could be delay and investigation and reporting is inaccurate and incomplete.

\section{ix. No special task force}

Land matters and waqf are two different fields. To understand the concept and conduct the process of waqf land registration is essential task. However, both land office and SIRCJ do not have the exact person who understand and knowledgeable about the both field. This is the cause of arrears file an application for registration of land ownership.

After all the issues in the waqf land registration are identified, solution is suggested to respondent. The respondent agreed as follow:

Table 3: Issue and Problem, Status and Effect/ Impact and Improvement Proposal from SIRCJ

\begin{tabular}{|c|c|c|c|c|c|}
\hline \multirow[b]{2}{*}{ No } & \multirow[b]{2}{*}{ Issue and Problem } & \multicolumn{2}{|l|}{ Status } & \multirow[b]{2}{*}{ Effect/ Impact } & \multirow[b]{2}{*}{ Improvement Proposal } \\
\hline & & SIRCJ & $\begin{array}{l}\text { Land } \\
\text { Office }\end{array}$ & & \\
\hline 1 & Bureaucracy & $\checkmark$ & $\checkmark$ & $\begin{array}{l}\text { Development planning } \\
\text { and development } \\
\text { cannot be done }\end{array}$ & $\begin{array}{l}\text { The established standards } \\
\text { guidelines the process in SIRCJ and } \\
\text { Land Office. }\end{array}$ \\
\hline 2 & $\begin{array}{l}\text { No adjustment among } \\
\text { agencies }\end{array}$ & $\checkmark$ & $\checkmark$ & $\begin{array}{l}\text { Waqf land ownership } \\
\text { solution cannot be } \\
\text { implemented }\end{array}$ & $\begin{array}{l}\text { Updated Johor Waqf Land } \\
\text { Management Books with details } \\
\text { process at the Land Office. }\end{array}$ \\
\hline 3 & $\begin{array}{l}\text { Late approval by State } \\
\text { Authority }\end{array}$ & & $\checkmark$ & $\begin{array}{l}\text { Idle land will be an } \\
\text { opportunity for the } \\
\text { invasion }\end{array}$ & $\begin{array}{l}\text { Submit a proposal for } \\
\text { consideration by the Government } \\
\text { to give special permission to land } \\
\text { intended for waqf. }\end{array}$ \\
\hline 4 & Objection heirs & $\checkmark$ & & $\begin{array}{l}\text { Status of waqf land can } \\
\text { be challenged in court }\end{array}$ & $\begin{array}{l}\text { Creation of Advisory Services Unit } \\
\text { of } W a q f .\end{array}$ \\
\hline 5 & $\begin{array}{l}\text { Ineffective } \\
\text { implementation }\end{array}$ & $\checkmark$ & $\checkmark$ & $\begin{array}{l}\text { Delays to the process of } \\
\text { registration of title }\end{array}$ & $\begin{array}{l}\text { Advanced Courses / training to the } \\
\text { officer involved }\end{array}$ \\
\hline
\end{tabular}




\begin{tabular}{|l|l|c|c|l|l|}
\hline 6 & $\begin{array}{l}\text { The length of time } \\
\text { through the process }\end{array}$ & $\checkmark$ & $\checkmark$ & $\begin{array}{l}\text { Late submission to State } \\
\text { Authority }\end{array}$ & $\begin{array}{l}\text { Update the SOP and do periodic } \\
\text { audit. }\end{array}$ \\
\hline 7 & Lack of staff & $\checkmark$ & & $\begin{array}{l}\text { The workload on } \\
\text { existing employees and } \\
\text { reduce the efficiency of } \\
\text { management }\end{array}$ & $\begin{array}{l}\text { Request vacancy staff from State } \\
\text { Authority }\end{array}$ \\
\hline 8 & No Land Expertise & $\checkmark$ & & $\begin{array}{l}\text { Investigation and } \\
\text { reporting is inaccurate } \\
\text { and incomplete }\end{array}$ & $\begin{array}{l}\text { Request Land Officer from State } \\
\text { Authority }\end{array}$ \\
\hline 9 & No special task force & $\checkmark$ & $\checkmark$ & $\begin{array}{l}\text { Arrears file an } \\
\text { application for } \\
\text { registration of land } \\
\text { ownership }\end{array}$ & $\begin{array}{l}\text { Creation of Task Force for Waqf } \\
\text { Application. }\end{array}$ \\
\hline
\end{tabular}

Based on Table 3, the suggestion for each issue are:

i. The established standards guidelines the process in SIRCJ and Land Office.

Both SIRCJ and Land Office suggested to have established standards guidelines as the process of waqf land registration system to be implemented in SIRCJ and Land Office.

ii. Updated Johor Waqf Land Management Books with details process at the Land Office.

All the process of waqf land registration needs to be record and update in a book in every Land Office at districts. This book shall be the manual or guidelines for land office to register the land as waqf because the SIRCJ will also use the same book as guideline. Hence, the procedure will be in line among SIRCJ and land office at every district in Johor.

iii. Submit a proposal for consideration by the Government to give special permission to land intended for waqf.

As the mechanical process involved in waqf land registration and caused the time consuming, therefore, it is suggested the government to give special permission to declared and endorsed the property as waqf land. However, the mechanical process shall continue as usual after the property is endorsed binding and shall not be cancelled.

iv. Creation of Advisory Services Unit of Waqf.

For the sake of heirs and waqif, if any issue is raised, the creation of advisory services unit of waqf shall make the process less costly and faster to resolve. The unit shall stand by experts in law of land matters and Islamic property.

\section{v. Advanced Courses / training to the officer involved}

In order to increase efficiency in delivery system, the staff and officer involved in waqf land registration system shall attend the advance coursed made by the experts of waqf property and land registration system. The course shall be made annually and update time to time according to improvement of the system.

vi. Update the SOP and do periodic audit.

The lengthy time and process shall be executed efficiently. The reason of late submission to local authority shall be identified and overcome. Thus, the process in future will become faster and easier to SIRCJ and Land Office 


\section{vii. Request vacancy staff from State Authority}

As in deficiency of staff in SIRCJ and Land Office, who knowledgeable about the land matters and waqf land. Thus, state authority shall provide staff in SIRCJ and Land Office who well known on land matters and waqf land registration system.

\section{viii. Request Land Officer from State Authority}

To improve process of registration system of waqf land in SIRCJ, state authority also need to assign the experts of land matter periodically or permanently to the SIRCJ.

\section{ix. Creation of Task Force for Waqf Application.}

As another alternative, Task Force for waqf application shall be created. By using the existing staff that is trained in the advance coursed or by existing experts available in Land Office and SIRCJ. They shall at least meet once in a month to update the status of waqf land at every district and enforce the right on the waqf land.

As the solutions imposed, the system of waqf land registration shall be improved. This solutions proposed is not only applicable in waqf land registration but also the the other land registration system. Hopefully, the finding of this research shall increase the efficiency of public delivery system in Malaysia and can be referred and used worldwide to other Islamic Country and any country which have Islamic Property.

\subsection{CONCLUSION}

Among many assets, land is the highly valuable. Land holds a unique and essential position in social, political, environmental and economic theories. It includes all natural resources, materials, airways, as well as the ground supporting all life and stands at the center of human culture and institutions. All people, at all times, must make use of land. Therefore, land is a valuable asset of every state. With the high demands, needs and scarcity of land, it is crucial for land to be registered and managed properly. Generally, waqf registration and its endorsement could be done through presentation of any instrument, document and written testimonial evidence proving the property being declared is waqf. However, compliance with Islamic and National Land Code is complex because they emphasise on different elements as perquisites of registration. Therefore, before making a proper improvement proposal each law shall be examined in details to ensure the suggestion is workable and relevant to the current needs of waqf and according to both system of law. Therefore, improvement proposals are needed for the issues and problems so then, in the future in title to waqf lands would be secured and welldeveloped to the best and highest use.

\section{Acknowledgement}

This research was supported by Skim Geran Penyelidikan Fundamental (Frgs) Fasa 1/2019: Universiti Teknologi Malaysia (UTM). We thank our colleagues from Universiti Teknologi Malaysia as the supporting institution that provided insight and expertise that greatly assisted the research

\section{List of Reference}

Afendi M. \& Sayuti (2012), Implikasi Perundangan Terhadap Pendaftaran Tanah Wakaf Malaysia. Satu Kajian Dari Aspek Akta Pengambilan Tanah. Retrieved from: Http://Www.Scribd.Com/Doc/81330622/Implikasi-Pendaftaran-Tanah-Wakaf 
Ali, A. (2009). Waqf Continued Relevance as the Third Sector in Terms of Mobilizing Resources for Productive Use in an Islamic Economic System. The Global University in Islamic Finance, Malaysia: Islamic Capital Market. FN 6603. 11

Augustinus, C. (2005). Islam, Land \& Property Research Series Paper 7: Waqf (Endowment) and Islamic Pbilanthropy. Retrieved from: http://www.landpedia.org/landdoc/Analytical_materials/ILP_1.pdf

Chepkwony, K. C. (2008). Islamic Philanthropy the Case of Waqf in Poverty Alleviation and Social Economic Development. Bologna University. (unpublished).

Crossman A. (2017) An overview to Chaos Theory in Sociology. ThoughtCo. Dotdash Press Publisher. Retrieved from: https://www.thoughtco.com/chaos-theory-3026621

Esmaeili, H. (2010) "The Relationship Between the Waqf Institution inIslamic Law and the Rule of Law in the Middle East." Flinders University, Australia

Farrar J. H. (1997). "Reasoning by Analogy in the Law". Bond University. 9(2).pp.30

G Rethinasamy Lwn Majlis Ugama Islam, Pulau Pinang Dan Satu Yang Lain, [1993] 2 Mlj 166 (Court Case)

Haji Embong Bin Ibrahim \& Ors V Tengku Nik Maimunah Hajjah Binte Almarhum Sultan Zainal Abidin \& Anor, [1980] $1 \mathrm{Mlj} 286$ (Court Case)

Hamid, A. M. I. and Tahir, M. S. M. (2014) Waqf Property - Concept, Management, Development, and Financing. Skudai: UTM Press Publisher.

Husain A. (2014). Muslim Personal Law. An Exposition- All India Personal Law Board. Uttar Pradesh, India: Open source. Retrieved from: http://muslimcanada.org/muspersonallaw.html\#about

Jamil K. (2012) Pekeliling Pengarah Tanah dan Galian Selangor Bilangan 3/2012, in: J. T. G. Persekutuan (Ed.), Selangor. pp. 11.

Kahf, M. (2012). Kinds and Objectives of Islamic Waqf. Role of Waqf In Sustainable Development. Retrieved from: http://monzer.kahf.com/papers/english/WAQF_A_QUICK_OVERVIEW.pdf

Kamali M.H. (1998). Principles of Islamic Jurisprudence, Kuala Lumpur, The Islamic Texts Society. ISBN10 0946621829.

Khassaf A. B. A. (1904). Kitab Ahkam al-Awqaf. Cairo: Diwan 'Umum al-Awqaf al-Misriyyah.

Knight A. \& Ruddox L., (2008). Advance Research Methods In The Built Enviroment, United Kingdom, WileyBlackwell.

Mahamood S.M. (2007). "Pembentukan Dana Wakaf Menurut Perspektif Syariah Dan Undang- Undang serta Aplikasinya di Malaysia". Jurnal Syariah, 15(2)

Majlis Agama Islam Selangor (Mais) V Bong Boon Chuen \& Ors [2008] 6 Mlj 48 (Court Case)

Mohamad N.A. et.al, (2012). Waqf Lands And Challenges From The Legal Perspectives In Malaysia, In Iium-Toyo Joint Symposium, I.I. University, Editor, Ahmad Ibrahim Kuliyyah Of Laws: Malaysia

Mohamood S.M. (2006). Waqf in Malaysia, Kuala Lumpur, University of Malaya Press.

Omar M.M. (2013). "Isu Pentadbiran Tanah Wakaf Dalam Konteks Ktn 1965 Dan Pejabat Tanah Dan Galian Negeri Sembilan”. Jurnal Pentadbiran Tanah

Osman Z. (2008). "Accountability in Managing Waqf Properties: The Case of Two States Religious Councils in Malaysia". School Of Management, Royal Holloway University of London. Doctor of Philosophy: Royal Holloway University of London, p. 348.

Pacific, U.O.S. (2003). Principles Relating to the Interpretation of Statutes and Constitutions. Port Vila, Vanuatu: PacLII. Retrieved from: http://www.vanuatu.usp.ac.fj/courses/LA304_Legal_Drafting/ LA304_Unit\%203.html 
Qudamah, I. A. (1947). al-Mughni li-Ibn Qudamah. Manchester University, United Kingdom: Copac. 567-68. Retrieved from: https://copac.jisc.ac.uk/id/36329607?style $=$ html

Rahaman C. M. S. et. al, (2011). "Economics Of Cash Waqf Management In Malaysia: A Proposed Cash Waqf Model For Practitioners And Future Researchers". African Journal of Business Management, Vol. 5

Ramli, M.I.A. (1938). Nihayat al-Muhtaj, Cairo: Open source. 368

Rukmana S. (2010). Profesionalisme Nazhir Dalam Pemeliharaan Dan Pengembangan Aset- Aset Wakaf Produktif, Fakultas Syariah Dan Hukum Uin Syarif Hidayatullah: Jakarta

Mohammad, M. T. S. H. (2013), A proposal for a new comprehensive Waqf law in Malaysia. Retrieved from http://waqfacademy.org/wp-content/uploads/2013/03/Mohammad-Tahir-SabitHaji-Mohammad.-Date.-Proposal-for-new-comprehensive-waqf-law-in Malaysia.pdf

Kader S.A., Zubaidah S., Dahlan M., Hilal N. (2009) Current legal issues concerning awqaf in Malaysia. In: International Conference. Waqf Laws \& Management: Reality and Prospects. Cultural Activity Centre (CAC), International Islamic University Malaysia, Gombak Campus.

Shafie, M.I. (1961). Al-Umm. Cairo: Dār al-Sha‘b. Retrieved from: https://catalog.hathitrust.org/Record/003046372 